\title{
Non-Linear Analysis of RC Building Considering Soil Structure Interaction
}

\author{
Prashant Amragol ${ }^{1}$ \\ ${ }^{1}$ M. Tech (Structural Engg.) \\ Student, Department of Civil Engineering, \\ KLEMSSCET, Belagavi, Karnataka, India.
}

\author{
Dr. Tejas. D. Doshi ${ }^{2}$ \\ ${ }^{2}$ Prof, Department of Civil Engineering, \\ KLEMSSCET, Belagavi, Karnataka, \\ India.
}

\begin{abstract}
Pushover analysis which is also stated as Non-linear static analysis is widely used procedures for the seismic assessment or evaluation of the structures. The pushover model is used to measure the new structure's seismic demand or for current structures. Within this research pushover review is carried out to consider $\mathbf{G + 1 0}$ multi-storeyed building in zones using SAP 2000 software From the results of the study it was discovered that the hinges are established between IO (Immediate Occupancy) and LS (Life Safety) suggesting that the building is secure. The structural model analysed in this state is therefore safe. Therefore, the structural model studied in this State is safe. The effect of interaction of the Soil Structure on the seismic efficiency of the construction is considered and the building is built with and without considering interaction of soilstructure (SSI).The RC building symmetric plan and These buildings are modelled, designed according to IS 456:2000 and evaluated using SAP2000 software under two separate boundary conditions, namely fixed-base, and considering nonlinear dynamic analysis soil-structure relationship.
\end{abstract}

Keywords- Seismic analysis, SAP 2000, Different plan configuration, pushover analysis, Soil structure interaction

\section{INTRODUCTION}

A structure must have four primary qualities, primarily easy and natural structure, sufficient lateral strength , stiffness and ductility .Buildings with simple standard configuration encounter significantly less harm in both design and elevation than irregular configuration. If a construction project requires uniformity and has inconsistency in configuration, mass or capacity-resistant elements, it is considered as irregular as per IS 1893-2002. These irregularities can cause problems in the continuity of the concentrations of force flow and stress.

Present study is primarily focused on identifying a structure 's behavior when it is exposed to certain action. The components of the complex include air, vibrations, traffic, blasts and earthquakes. Any design can be subjected to unpredictable load.Structural configuration may be an important problem for weak performance of buildings performance of the building serious earthquakes, imbalance certainly lead to high lateral load, excessive capacity of the structure and eventually the buildings damage.

\section{OBJECTIVE OF THE STUDY}

$>$ Generation of 3D building models using SAP 2000 software. ^

$>$ To evaluate the lateral load on various construction models
$>$ To study comparison between regular and Irregularities building of the structures pushover analysis and soil structure interactions

$>$ To carry out pushover analysis as per document (FEMA 356)

$>$ Along with code as per IS 1893:2002 (part- 1) for regular RC and different plan irregularities

$>$ To study behavior of the structure due to formation of hinges under different stages

\section{METHODOLOGY}

The following approach is considered in the present study in order to achieve the objectives mentioned above.

\section{Development of $G+10$ storied $R C$ bare frame model}

RC bare frame model ( $\mathrm{G}+10)$ having different plan irregularities viz, Rectangular, shape L shape ,H shape, U shape are developed using SAP 2000 (Ver 14) M25 grade concrete for beams, M25 grade concrete for columns and Fe $500 \mathrm{Mpa}$ grade of steel for reinforcement are taken as material properties. Dead load and Live load acting on the frame are taken as per IS 875 (Part1) and IS 875 ( Part 2), codal provisions respectively. and zone IV of IS 1893 (Part 1 2002) is considered in the development of RC frame models.

\section{Seismic Analysis for the developed RC frame models}

The RC frame models developed are receptively subject to Pushover's study and soil structure interaction (SSI).It also performs equivalent static and response spectrum test to evaluate the model's seismic response.

\section{Comparison of Analysis results}

Comparison is made for this with the response of interaction with and without soil characteristics such as (Hard, Medium, Soft) on the performance of developed RC frame models with Pushover analysis in mind.

\section{Description of the Building}

In the various different lateral force resisting system is considered for building $\mathrm{RC}$ frame with interaction of soil structure.The design and elevations of the considered construction designs are shown in figure

Model 1: Rectangular model Bare frame With and without soil structure interaction

Model 2: H model bare frame with and without soil structure interaction

Model 3: L model bare frame with and without soil structure interaction

Model 4: U model bare frame with and without soil structure interaction 


\section{Material Properties}

The materials used during construction is concrete reinforced with concrete gradeM-25 and steel gradeFe-415.The basic properties of the material are given in table 5.1

\begin{tabular}{|c|c|}
\hline Material Properties & Values \\
\hline Characteristic strength of concrete, $\mathrm{f}_{\mathrm{ck}}$ & $25 \mathrm{Mpa}$ \\
\hline Yield stress for steel, $\mathrm{F}_{\mathrm{y}}$ & $500 \mathrm{Mpa}$ \\
\hline Modulus of Elasticity of steel, Es & $20,000 \mathrm{Mpa}$ \\
\hline Modulus of Elasticity of concrete, $\mathrm{Ec}$ & $25000 \mathrm{Mpa}$ \\
\hline
\end{tabular}

\subsection{Structural details}

\begin{tabular}{|c|c|}
\hline Plan Dimensions & $32 \times 24 \mathrm{~m}$ \\
\hline No. of bays in x direction & 9 \\
\hline No .of bays in y direction & 7 \\
\hline Spacing in x direction & 4 \\
\hline Spacing in y direction & 4 \\
\hline No of storey & 10 \\
\hline Plinth beam size & $230 \times 450 \mathrm{~mm}$ \\
\hline Beam size & $450 \times 450 \mathrm{~mm}$ \\
\hline \multirow{2}{*}{ Column size } & $\begin{array}{c}600 \times 600 \mathrm{~mm}(\text { basement } \\
\text { to } 5^{\text {th }} \text { storey) }\end{array}$ \\
\cline { 2 - 2 } & $\begin{array}{c}450 \times 45 \mathrm{~mm}\left(6^{\text {th }} \text { to } 10^{\text {th }}\right. \\
\text { storey) }\end{array}$ \\
\hline Slab thickness & $125 \mathrm{~mm}$ \\
\hline Height of each storey & $3.0 \mathrm{~m}$ \\
\hline Foundation height & $1.5 \mathrm{~m}$ \\
\hline
\end{tabular}

\subsection{Seismic design data}

\begin{tabular}{|c|c|}
\hline Live load & $3.0 \mathrm{kN} / \mathrm{m} 2$ on floor \\
\cline { 2 - 2 } & $1.5 \mathrm{kN} / \mathrm{m} 2$ on roof \\
\hline Wall load & $11.73 \mathrm{kN} / \mathrm{m}$ \\
\hline Parapet load & $4.6 \mathrm{kN} / \mathrm{m}$ \\
\hline Seismic load & IS $1893: 2002$ (Part 1$)$ \\
\hline Seismic zone & IV \\
\hline Importance factor (I) & 1 \\
\hline Response reduction (R) & 3 \\
\hline
\end{tabular}

\subsection{Calculated soil spring values as per Richart and Lysmer}

\begin{tabular}{|c|c|c|}
\hline $\begin{array}{c}\text { Type of } \\
\text { Soil }\end{array}$ & Equivalent radius & Spring values \\
\hline \multirow{4}{*}{ Hard } & $\mathrm{r}_{\mathrm{z}}=9.59$ & $\mathrm{~K}_{\mathrm{z}}=4215384.78$ \\
\cline { 2 - 3 } & $\mathrm{r}_{\mathrm{x}}=9.59$ & $\mathrm{~K}_{\mathrm{x}}=\mathrm{K}_{\mathrm{y}}=3592240.94$ \\
\cline { 2 - 3 } & $\mathrm{r}_{\varnothing_{\mathrm{x}}}=9.70$ & $\mathrm{~K}_{\varnothing_{\mathrm{x}}}=284249.95$ \\
\cline { 2 - 3 } & $\mathrm{r}_{\varnothing_{\mathrm{y}}}=9.70$ & $\mathrm{~K}_{\varnothing_{\mathrm{y}}}=2842490.95$ \\
\cline { 2 - 3 } & $\mathrm{r}_{\varnothing_{\mathrm{z}}}=9.70$ & $\mathrm{k}_{\varnothing_{\mathrm{z}}}=3979487.33$ \\
\hline \multirow{4}{*}{ Medium } & $\mathrm{r}_{\mathrm{z}}=9.59$ & $\mathrm{~K}_{\mathrm{z}}=684999.63$ \\
\cline { 2 - 3 } & $\mathrm{r}_{\mathrm{x}}=9.59$ & $\mathrm{~K}_{\mathrm{x}}=\mathrm{K}_{\mathrm{y}}=519157.61$ \\
\cline { 2 - 3 } & $\mathrm{r}_{\varnothing_{\mathrm{x}}}=9.70$ & $\mathrm{~K}_{\varnothing_{\mathrm{x}}}=461904.51$ \\
\cline { 2 - 3 } & $\mathrm{r}_{\varnothing_{\mathrm{y}}}=9.70$ & $\mathrm{~K}_{\varnothing_{\mathrm{y}}}=461904.51$ \\
\cline { 2 - 3 } & $\mathrm{r}_{\varnothing_{\mathrm{z}}}=9.70$ & $\mathrm{k}_{\varnothing_{\mathrm{z}}}=554285.41$ \\
\hline \multirow{4}{*}{ Soft } & $\mathrm{r}_{\mathrm{z}}=9.59$ & $\mathrm{~K}_{\mathrm{z}}=288601.80$ \\
\cline { 2 - 3 } & $\mathrm{r}_{\mathrm{x}}=9.59$ & $\mathrm{~K}_{\mathrm{x}}=\mathrm{K}_{\mathrm{y}}=205416.58$ \\
\cline { 2 - 3 } & $\mathrm{r}_{\varnothing_{\mathrm{x}}}=9.70$ & $\mathrm{~K}_{\varnothing_{\mathrm{x}}}=194608.10$ \\
\cline { 2 - 3 } & $\mathrm{r}_{\varnothing_{\mathrm{y}}}=9.70$ & $\mathrm{~K}_{\varnothing_{\mathrm{y}}}=194608.10$ \\
\cline { 2 - 3 } & $\mathrm{r}_{\varnothing_{\mathrm{z}}}=9.70$ & $\mathrm{k}_{\varnothing_{\mathrm{z}}}=214068.91$ \\
\hline
\end{tabular}
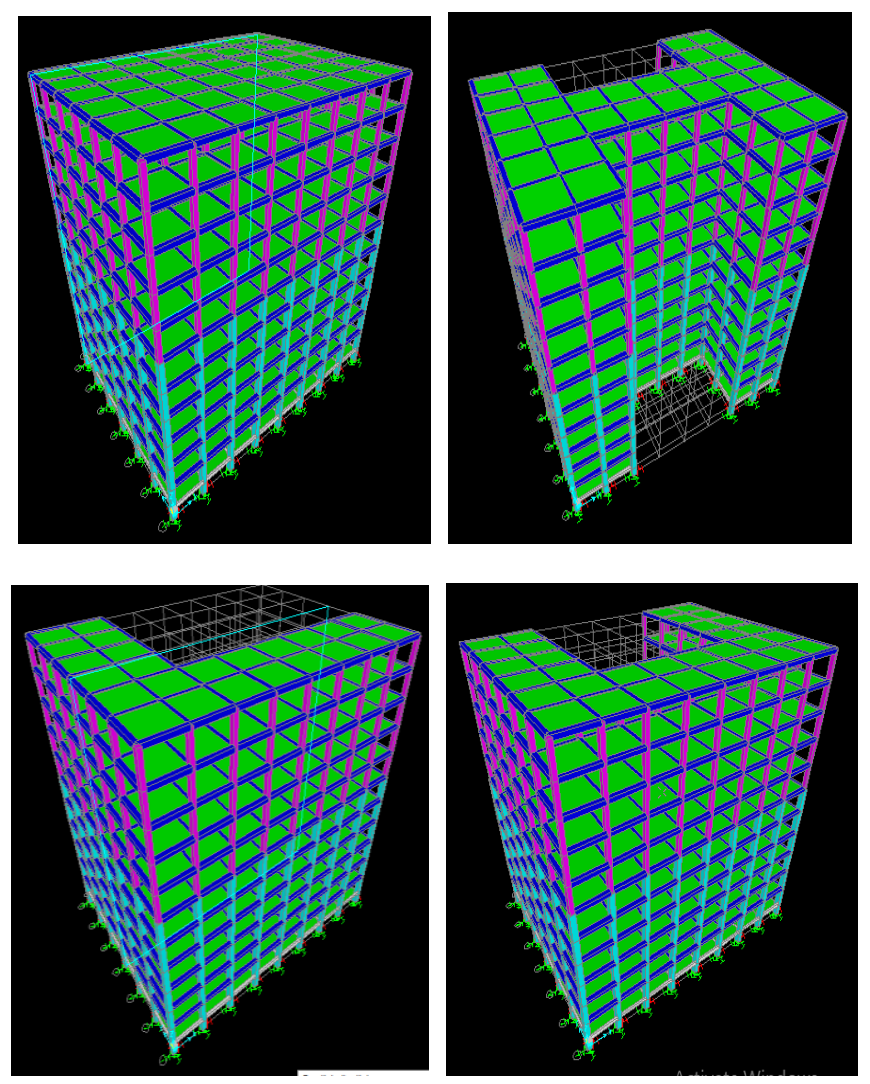

\subsection{Global Stiffness}

The ratio of base force and displacement at the performance point is known as global stiffness of the structure. The stiffness of building is computed to study the deformations in the building models.

Table 5.4Global stiffness

\begin{tabular}{|c|c|c|c|}
\hline Model No. & $\begin{array}{c}\text { Base force (F) at } \\
\text { performance point }\end{array}$ & $\begin{array}{c}\text { Displacement (8) } \\
\text { at performance } \\
\text { point }\end{array}$ & $\begin{array}{c}\text { Stiffness (F/o) } \\
\mathbf{k N} / \mathbf{m m}\end{array}$ \\
\hline 1 & 10431.305 & 115 & 90.77 \\
\hline 2 & 10963.490 & 138 & 79.44 \\
\hline 3 & 8730.096 & 130 & 67.15 \\
\hline 4 & 11063.500 & 136 & 81.34 \\
\hline 5 & 15049.161 & 156 & 96.46 \\
\hline 6 & 10912.763 & 163 & 66.94 \\
\hline 7 & 8613.172 & 149 & 57.80 \\
\hline 8 & 10902.686 & 156 & 69.88 \\
\hline 9 & 8930.040 & 209 & 42.72 \\
\hline 10 & 6563.691 & 210 & 31.255 \\
\hline 11 & 5131.918 & 200 & 25.65 \\
\hline 12 & 6544.42 & 202 & 32.39 \\
\hline 13 & 7597.416 & 259 & 29.33 \\
\hline 14 & 5605.750 & 259 & 21.64 \\
\hline 15 & 4376.166 & 247 & 17.71 \\
\hline 16 & 5600.970 & 257 & 21.79 \\
\hline
\end{tabular}



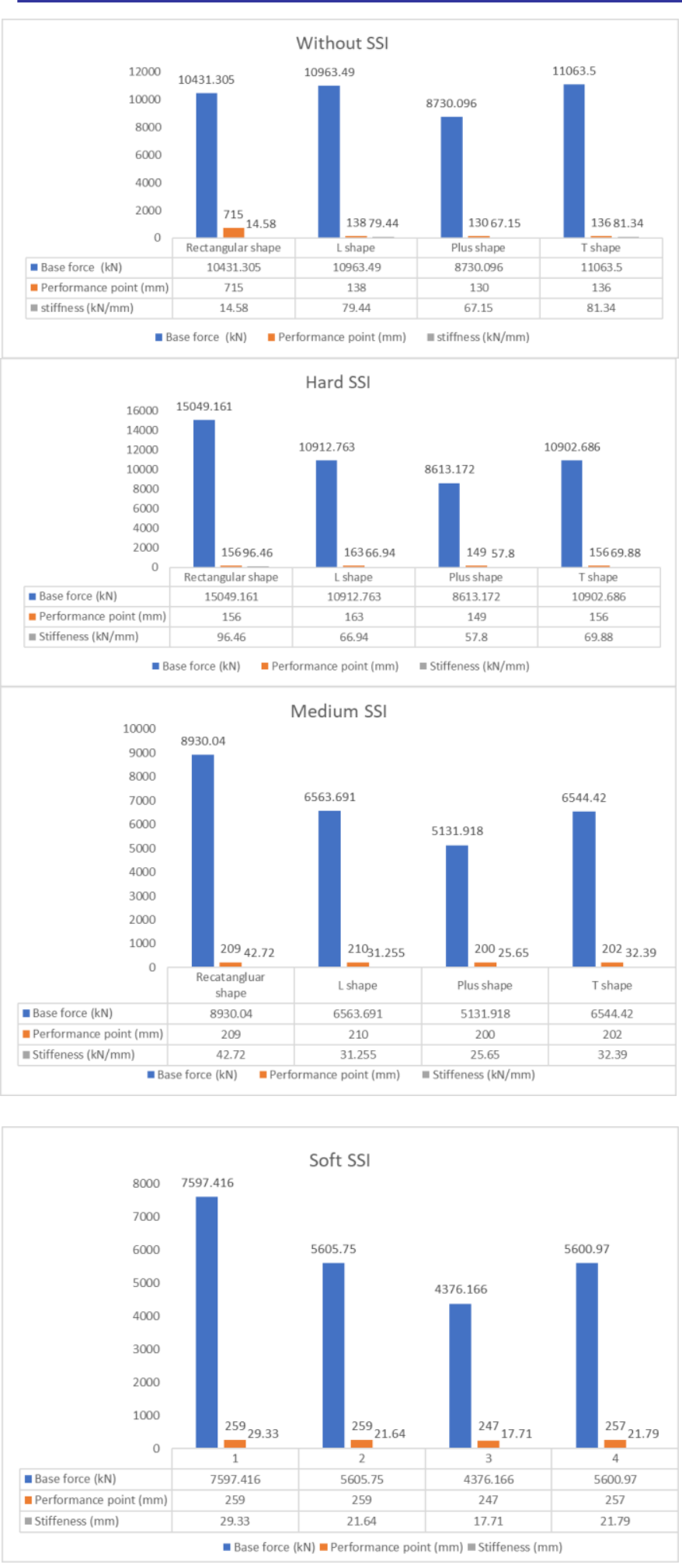

\section{5 .CONCLUSION}

The report is concluded for each of the building models assumed for the linear and non-linear analysis performed by SAP 2000. The conclusion is presented on the undamped natural period, base force, roof displacement, hinges area and global rigidity for different construction models.

Compared with results reported for the various building models from different analyzes.
Taking into Take account of the earthquake codes described in the ways to reduce risk to earthquake shaking, RCC framed multi-story building must be designed.

> Codal and analytical time periods do not match each other as codal estimation is based on empirical formulae.

$>$ The minimum natural period from following building considerations

Dithout soil structure interaction

> Types of soil considerations i.e for hard sec, medium sec, and soft sec

$>$ The performance point for the various buildings as the base force increases the roof displacement decreases building can be performed from the following considerations a)Types of soil consideration for

Hard $\mathrm{V}=15049.0161 \mathrm{kN}$ and $\mathrm{D}=156 \mathrm{~mm}$ Medium $\mathrm{V}=8930.040 \mathrm{kN}$ and $\mathrm{D}=210 \mathrm{~mm}$ Soft $\mathrm{V}=7597.417 \mathrm{kN}$ and $\mathrm{D}=258 \mathrm{~mm}$

$>$ The maximum number of hinges have formed between IO-LS which means, very limited structural damage and risk to life is negligible and significant damage to structural elements with some residual strength, risk to life from structural damage is very low.

$>$ It is found that rectangular structures are more deformed than symmetrical designs and thus, when building a new structure in a high seismic environment, it is more likely to create a structure that is symmetrical in shape in order to provide greater stability.

\section{REFERENCES}

[1] Rakesh Yadav , Dr.Trilok Gupta and Dr. Ravi Kr. Sharma “ Performance levels of Rc Structures by Non- Linear pushover Analysis" (IJERA)-Volume 7, Issue 4, (Part-2) April 2017

[2] Akshay V. Raut And Prof. RVRK Prasad "Pushover Analysis of G+3 Reinforced Concrete Building with Soft storey" (IOSR-JMCE)Volume 11, Issue 4, (july-Aug.2014)

[3] Prof. Milind V .Mohod " Pushover Analysis of Structure with plan Irregularity" (IOSRJMCE)- Volume 12, Issue 4, (july-Aug.2015)

[4] Neethu K.N and Saji.K.P " Pushover analysis of RC Building” (IJSR)- Volume 4, Issue 8, August 2015

[5] Abhilash D. K , Dr. M. D. Vijayanand "Pushover Analysis of a Multi-Storied Building in Two Different Zones" (IJIRSET)-Volume 8, Issue6, June 2019

[6] Dr. MOHD HAMRAJ (2014) performed the“ performance based pushover analysis of

[7] R.C.C frames for plan irregularity" (IJSET)- Volume 2, Issue 7, (Oct 2019)

[8] Phanikumar V ,Saikiran K “ Non -Linear Dynamic Analysis of Multistoried Reinforced Concrete Building by Considering Soil structure interaction" (IJITEE)- Volume 7,Issue 7 (April 2018)

[9] Prof. Dilip J.Chaudhari, Nikhil N. Chopade "Performance Based Seismic Design of RC Building with Consideration Of Soil Structure Interaction" (IRJET)-Volume 5, Issue 5, (May 2018)

[10] Veena S Ravi, SreedeviLekshmi (2016) "Effect of Shape and Plan Configuration on Seismic Response of Structure (Zone II \&IV)" International Journal of Science and Research..

[11] UmalChandekar ,A.P.Khatri (2015) "Effect of Soil Structure Interaction on Seismic analysis of Structure" Journal of Civil Engineering and Environmental Technology.

[12] Nirav M. Katarmal, Hemal J.Shah (2016) "Seismic Response of RC Irregular Frame with SoilStructure Interaction" International Journal of Scientific Development and Researc 
[13] IS: 1893 (Part 1). (2002). "Criteria of Earthquake Resistant Design of Structures", Fifth revision. BIS New Delhi. BIS,

[14] IS: 857-1987., Code of Practice for Design Loads (other than Earthquake) and Reinforced Concrete, Buildings and Structures, Part $(1,2)$, Second Revision.

[15] IS 456: (2000). Plain and reinforced concrete code of practice, fourth revision, Bureau of Indian Standard.

[16] ATC, 1996, Seismic Evaluation and Retrot of Concrete Buildings, Volume 1, ATC-40 Report, Applied Technology Council, Redwood City, California.

[17] Federal Emergency Federal Agency, FEMA-356. Pre-standard and Commentary for Seismic Rehabilitation of Buildings. Washington DC, 2000.

Prashant Amaragol

\section{AUTHORS}

PG Student, Structural Engineering,

Department of Civil Engineering,

KLEMSSCET Belagavi, Karnataka, India

Dr. Tejas Doshi,

Professor, Department of Civil Engineering,

KLEMSSCET Belagavi, Karnataka, India 